\title{
PROFIL NELAYAN PENANGKAP IKAN DEMERSAL DI KAMPUNG LAOTONGAN (PULAU TEHANG) KECAMATAN TABUKAN SELATAN KABUPATEN KEPULAUAN SANGIHE
}

\author{
Costantein Imanuel Sarapil $^{1, \square)}$, Ishak Bawias ${ }^{2)}$, Eunike Irene Kumaseh ${ }^{3)}$, \\ Getruida Nita Mozes ${ }^{4)}$, Ganjar Ndaru Ikhtiagung ${ }^{5)}$, Reinaldi Menggalebose ${ }^{6}$ \\ 1,2,3,4,6 Jurusan Perikanan dan Kebaharian, Politeknik Negeri Nusa Utara, \\ ${ }^{5}$ Politeknik Negeri Cilacap \\ e-mail : ${ }^{1}$ sarapilcostantein79@gmail.com
}

\begin{abstract}
This study aims to determine the marketing margins of demersal fish in Laotongan Village. Laotongan Village, or another name for Tehang Island, is one of the islands in District of Tabukan Selatan, Regency of Sangihe Archipelago. The method used is qualitative and quantitative methods. Qualitative methods are methods that look at phenomena from non-material aspects, beyond what they appear to be, with the study of meaning as something holistic. Meanwhile, the quantitative method is a method that looks at the phenomenon from the material aspect, which is visible, the impact study, the factors that affect it as a variable. In general, fisher who catch fish in Laotongan Village use hand line, in the local language it is called Kakintu. Also, the type boat used is pumpboat. The fisher in Laotongan Village are fisher with low income, and most of the fisher have an elementary education level. Marketing margin of Demersal fish is Rp. 15,000., And the efficiency of the portion received by fisher, $F=57 \%, F>50 \%$, where the sales of demersal fish are efficient. However, fisher's welfare has not improved. One of the factors is the extravagant fisher's lifestyle. The government can pay attention to the welfare of fisher.
\end{abstract}

Keywords : fisher; marketing margin; demersal fish; laotongan village; tehang island.

\begin{abstract}
ABSTRAK
Penelitian ini bertujuan untuk mengetahui kondisi sosial ekonomi nelayan di Kampung Laotongan. Kampung Laotongan, atau nama lain dari Pulau Tehang, merupakan salah satu pulau yang ada di Kecamatan Tabukan Selatan Kabupaten Kepulauan Sangihe. Metode yang digunakan adalah metode kualitatif dan kuantitatif. Metode kualitatif adalah metode yang melihat fenomena dari aspek non materi, dibalik yang tampak, dengan kajian makna sebagai sesuatu yang holistik. Sedangkan metode kuantitatif adalah metode yang melihat fenomena dari aspek materi, yang tampak, kajian dampak, faktor-faktor yang mempengaruhi sebagai suatu gabungan variabel. Umumnya, nelayan penangkap ikan demersal di Kampung Laotongan menggunakan alat tangkap hand line, dalam Bahasa lokal disebut Kakintu. Serta, perahu yang digunakan adalah perahu jenis pumpboat. Nelayan di Kampung Laotongan merupakan nelayan dengan pendapatan yang rendah, serta sebagian besar nelayan mempunyai pendidikan tingkat SD. Margin pemasaran ikan demersal sebesar Rp. 15.000,-, dan nilai efesiensi bagian yang diterima nelayan, $F=57 \%, F>50 \%$, dimana hasil penjualan ikan demersal sudah efisien. Namun, kesejahteraan nelayan tidak meningkat. Salah satu faktor yaitu gaya hidup nelayan yang boros. Pemerintah dapat lebih memperhatikan kesejahteraan nelayan.
\end{abstract}

Kata kunci : nelayan; margin pemasaran; ikan demersal; kampung laotongan; pulau tehang.

\section{PENDAHULUAN}

Nelayan tradisional adalah nelayan dengan peralatan tangkap tradisional, modal usaha kecil, serta teknologi penangkapan ikan yang relatif sederhana (Yapanani, dkk, 2013). Masyarakat nelayan umumnya tinggal di wilayah pesisir dengan mata pencaharian memanfaatkan potensi laut (Rosni,
2017). Kondisi usaha nelayan di wilayah pesisir mengandung faktor ketidakpastian yang cukup tinggi sehingga berdampak pada ketimpangan kesejahteraan rumah tangga nelayan (Firdaus \& Witomo, 2014).

Kabupaten Kepulauan Sangihe ini dari luas geografi 80 persen luasnya didominasi oleh laut, dan dikelilingi oleh 
pulau-pulau kecil. Salah satu pulau yaitu pulau Tehang yang terletak di bagian Selatan Kabupaten Kepulauan Sangihe, pada tahun 2004 oleh Pemerintah Kabupaten Kepulauan Sangihe telah dimekarkan menjadi satu kampung dan ditetapkan menjadi Kampung Laotongan. Kampung Laotongan mempunyai sumberdaya perikanan yang besar, terbukti melalui hasil tangkapan nelayan yang melimpah.

Kampung Laotongan dikelilingi oleh laut sehingga masyarakat setempat bergantung pada hasil laut atau kebanyakan masyarakat di kampung ini bermata pencaharian sebagai nelayan. Ikan hasil tangkapan tersebut dijual oleh nelayan setempat ke pasar Manalu di Kampung Lesabe 1 Kecamatan Tabukan Selatan. Sebagian besar penduduk di Kampung Laotongan mempunyai pekerjaan sebagai nelayan, yaitu sebesar 29 \%. Dan, pekerjaan lainnya sebesar 58 $\%$.

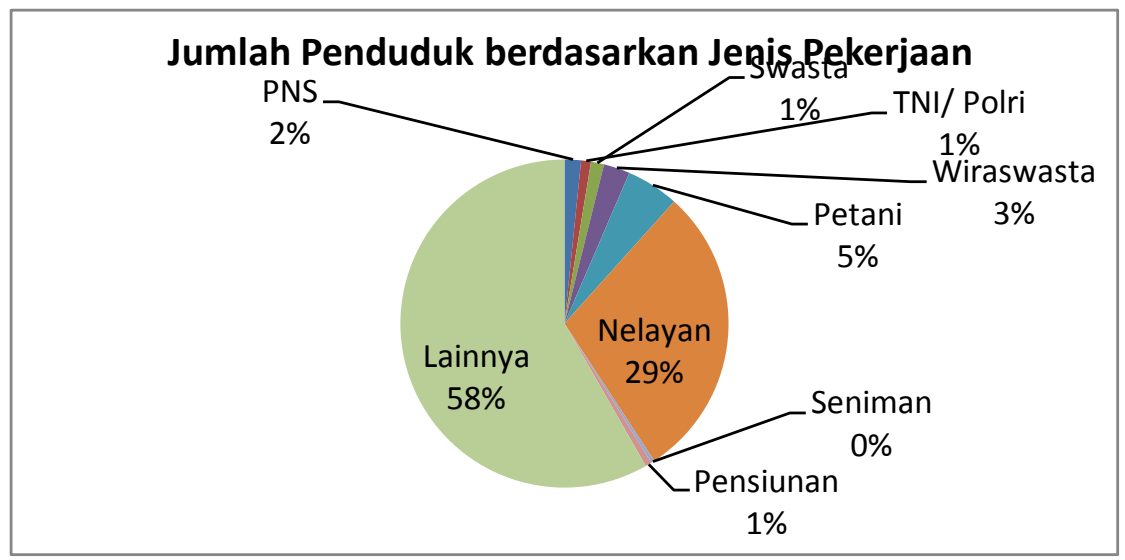

Gambar 1. Jumlah Penduduk berdasarkan jenis pekerjaan.

Pemasaran ikan demersal bagi nelayan di Kampung Laotongan menentukan seberapa besar keuntungan yang mereka peroleh. Penelitian ini bertujuan untuk mengetahui kondisi sosial ekonomi nelayan serta saluran pemasaran ikan demersal di Kampung Laotongan.

\section{METODE PENELITIAN}

Penelitian ini dilakukan pada bulan Maret - Mei 2020 di Kampung Laotongan atau disebut juga dengan Pulau Tehang, Kecamatan Tabukan Selatan Kabupaten Kepulauan Sangihe Propinsi Sulawesi Utara. Lokasi penelitian ditunjukkan pada Gambar 2.

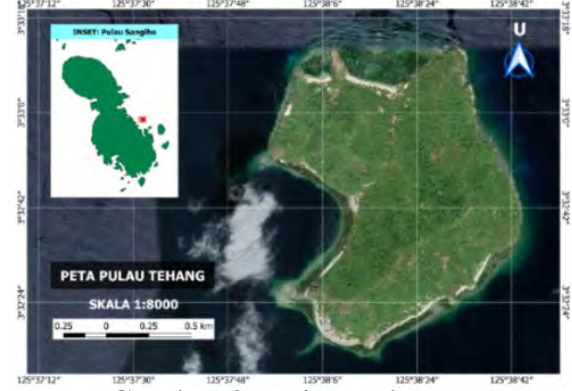

Gambar 2. Pulau Tehang

Metode yang digunakan dalam penelitian ini yaitu metode kualitatif dan kuantitatif. Metode kualitatif adalah metode yang melihat fenomena dari aspek non materi, di balik yang tampak, dengan kajian makna sebagai sesuatu yang holistik. Sedangkan metode kuantitatif adalah metode yang melihat fenomena dari aspek materi, yang tampak, kajian dampak, faktor-faktor yang mempengaruhi sebagai suatu gabungan variabel (Subadi,2004). Menurut Triyanti \& Shafitri (2012), 
perhitungan margin pemasaran yaitu sebagai berikut:

$$
\boldsymbol{M}_{\boldsymbol{p}}=\boldsymbol{P}_{\boldsymbol{r}}-\boldsymbol{P}_{\boldsymbol{f}}
$$

dimana,

$M_{p}$ : Margin pemasaran ikan demersal $(\mathrm{Rp} / \mathrm{kg})$

$P_{r} \quad$ : Harga ikan demersal ditingkat konsumen $(\mathrm{Rp} / \mathrm{kg})$

$P_{f} \quad$ : Harga ikan demersal yang diterima produsen $(\mathrm{Rp} / \mathrm{kg})$

Persentase margin pemasaran, $M_{p}$, yaitu dihitung sebagai berikut.

$$
M_{p}=\left(\frac{P_{r}-P_{f}}{P_{r}}\right) \times 100 \%
$$

Harga yang diterima produsen (nelayan), $F$ sebagai berikut.

$$
F=\left(\frac{1-M}{P_{r}}\right) \times 100 \%
$$

dimana $F>50 \%$ artinya pemasaran dikatakan efisien, $F<50 \%$ artinya pemasaran belum efisien.

Teknik pengambilan data dilakukan dengan observasi dan pengamatan langsung di lapangan. Data yang diperoleh melalui pengamatan langsung di lapangan terbagi menjadi dua yaitu, data primer dan data sekunder. Data primer merupakan data yang diperoleh dari hasil wawancara kepada nelayan, penjual dan konsumen tentang :

a. Rincian biaya operasional per trip

b. Rincian hasil penjualan dari produsen (nelayan)

c. Rincian harga beli konsumen

Sedangkan data sekunder adalah data yang diperoleh dari perpustakaan, studi literatur, jurnal, dan literatur lainnya.

\section{HASIL DAN PEMBAHASAN}

Pulau Tehang, sering disebut juga dengan Kampung Laotongan, merupakan wilayah administrasi Kecamatan Tabukan Selatan Kabupaten Kepulauan Sangihe, dengan luas wilayah $420 \mathrm{Ha}$, dan batas-batas wilayah sebagai berikut. Kampung Laotongan ditunjukkan pada Gambar 3.
- Utara : Laut Sulawesi

- Timur : Selat Batuwingkung

- Selatan : Selat Manalu

- Barat : Selat Simueng Gambar 3. Kampung Laotongan (a); Pesisir
Pantai Kampung Laotongan (b).

Sebagian besar penduduk di Kampung Laotongan mempunyai tingkat pendidikan sampai di tingkat SD (Sekolah Dasar), seperti yang ditunjukkan pada Gambar 4. Salah satu hal yang mendasari tingkat pendidikan masyarakat yang rendah yaitu minimnya pendapatan sehingga sebagian besar masyarakat Kampung Laotongan tidak dapat melanjutkan sekolah ke jenjang yang lebih tinggi.
Gambar 4. Jumlah Penduduk berdasarkan Tingkat Pendidikan. 
Sebagian besar, penduduk di Kampung Laotongan beragama Kristen Protestan, yaitu jumlah penduduk yang memeluk agama Kristen sebesar 97,73 \% (302 orang) dan yang memeluk agama Islam sebesar 2,27 \% (7 orang). Namun, hal tersebut tidak menjadi kendala untuk terjalinnya tali silahturami yang baik antarwarga kampung Laotongan. Menurut Sarapil, dkk (2019), hubungan sosial nelayan sangat tinggi dimana solidaritas mereka ditunjukkan melalui gotong royong, ataupun dalam kegiatan sosial lainnya.

Nelayan di Kampung Laotongan menggunakan alat tangkap hand line (dalam Bahasa lokal disebut Kakintu, dan menggunakan perahu katir jenis pumpboat, yaitu jenis perahu katir yang digerakan oleh mesin penggerak untuk melakukan operasi penangkapan ikan, seperti yang ditunjukkan pada Gambar 6 .
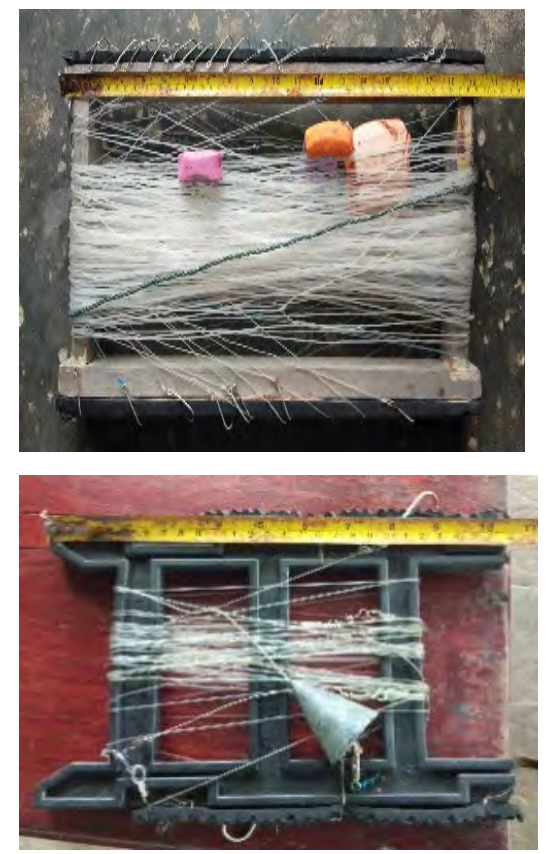

Gambar 5. Alat Tangkap Hand Line (kakintu)

Alat tangkap hand line (kakintu) terdiri atas beberapa bagian seperti penggulung tali, tali utama, tali cabang, pelampung, pemberat, dan mata pancing. Menurut Sarapil \& Lungari (2017), kesiapan teknologi nelayan masih sangat rendah, membutuhkan pengembangan yang besar. Pemerintah dapat memperhatikan penggunaan alat tangkap nelayan. Alat tangkap hand line (kakintu) ditunjukkan pada Gambar 5.

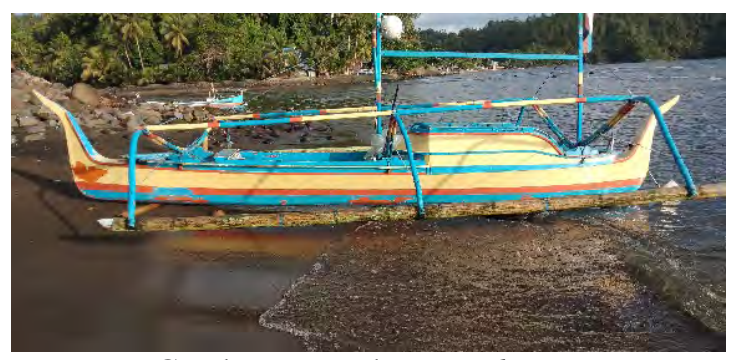

Gambar 6. Perahu Pumpboat

Operasi penangkapan ikan dilakukan pada malam hari mulai dari Pukul 18.00 - 23.00 WITA, kemudian kembali lagi ke fishing base. Setelah itu, hasil tangkapan diletakkan di dalam cool box yang berisi es untuk menjaga kesegaran ikan. Pukul 05.30 WITA, nelayan membawa hasil tangkapan ke pesisir pantai kampung Lesabe Kecamatan Tabukan Selatan. Di pesisir pantai tersebut, hasil tangkapan dibeli oleh pedagang pengumpul dan pedagang pengecer. Beberapa jenis ikan hasil tangkapan yang diperoleh yaitu Kurisi, Kakatua, Kulit Pasir, Kerapu dan Kakap, seperti yang ditunjukkan pada Tabel 1. Hasil tangkapan tersebut kemudian dijual ke pasar Manalu. 
Tabel 1. Hasil Tangkapan Ikan Demersal

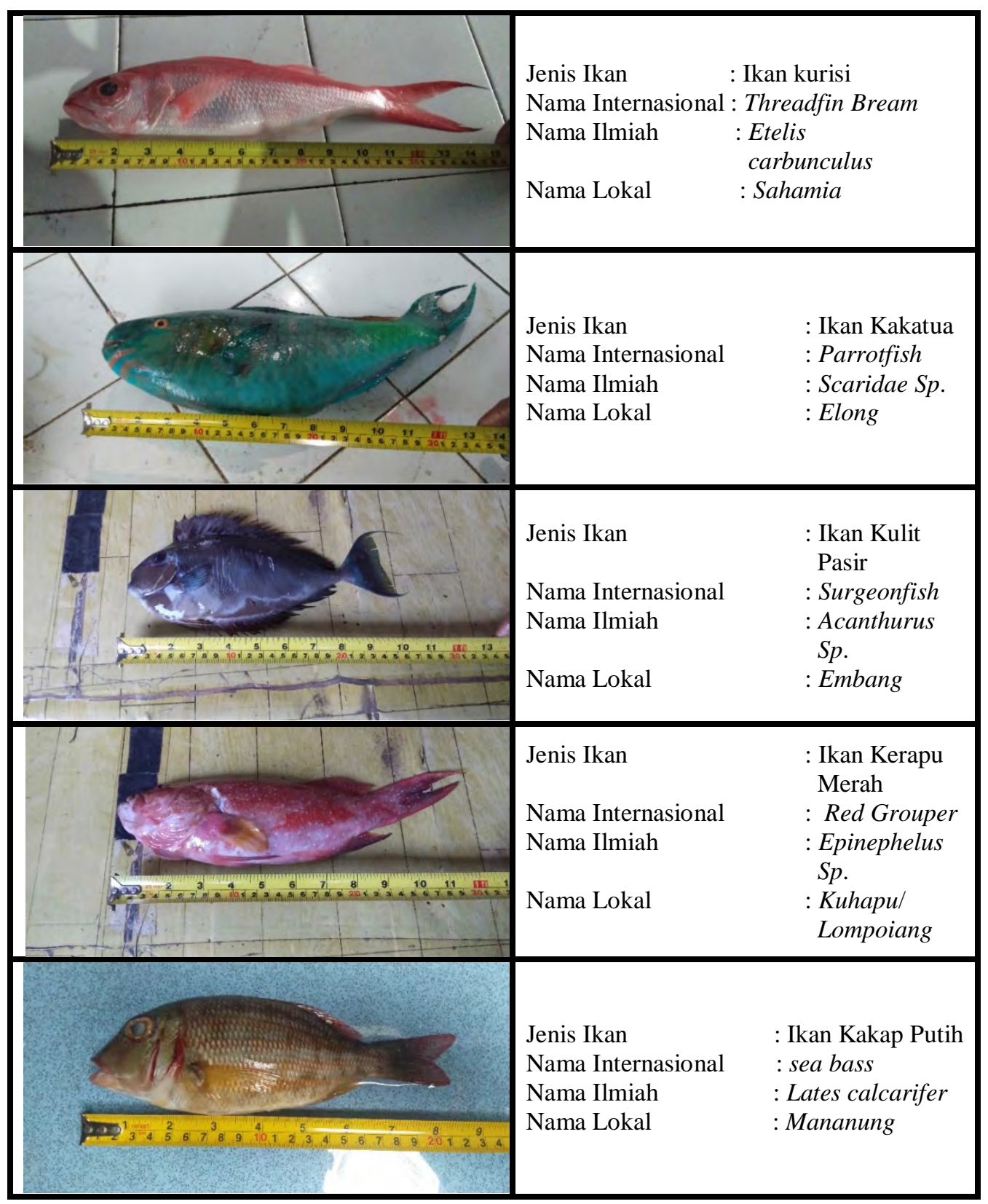

Pesisir pantai Kampung Lesabe juga merupakan tempat parkir perahu perahu nelayan dari Pulau Tehang, dan pulau lainnya. Biaya untuk melaut per trip bagi nelayan di Kampung Laotongan ditunjukkan pada Tabel 2.

Tabel 2. Pengeluaran Nelayan Per Trip

\begin{tabular}{lc}
\hline \multicolumn{1}{c}{ Jenis Biaya } & $\begin{array}{c}\text { Jumlah } \\
\text { (Rp) }\end{array}$ \\
\hline Bensin (BBM) 7 Liter & 70.000 \\
\hline Rokok 2 bungkus & 20.000 \\
\hline Es 10 bungkus & 10.000 \\
\hline
\end{tabular}

\begin{tabular}{cr}
\hline Umpan (Ikan Layang) & 30.000 \\
\hline Jumlah Pengeluaran & $\mathbf{1 3 0 . 0 0 0}$ \\
\hline
\end{tabular}

Rata- rata hasil tangkapan nelayan per trip ditunjukkan pada Tabel 3. 
Tabel 3. Rata - rata Hasil Tangkapan Nelayan Per Trip

\begin{tabular}{lccc}
\hline $\begin{array}{c}\text { Hasil } \\
\text { Tangkapan }\end{array}$ & $\begin{array}{c}\text { Jumlah } \\
\text { Tangkapan } \\
\text { (kg) }\end{array}$ & $\begin{array}{c}\text { Harga } \\
\text { (Rp/kg) }\end{array}$ & $\begin{array}{c}\text { Jumlah } \\
\text { (Rp) }\end{array}$ \\
\hline Ikan & 20 & 20.000 & 400.000 \\
Demersal & & & \\
- Kurisi & & & \\
- Kakatua & & & \\
- Kulit Pasir & & & \\
- Kerapu & & & \\
& & & \\
\hline
\end{tabular}

Keuntungan yang diperoleh nelayan = hasil penjualan - modal (biaya melaut) Rp 270.000,- dengan persentase untung sebesar 32,5 \%. Jika dalam seminggu, ada 3x nelayan menjual ikan di pasar Manalu, , maka pendapatan nelayan dalam 1 bulan $=\operatorname{Rp} 270.000,-x 3 \times 4$ minggu $=$ Rp 3.240.000,- . pendapatan ini pun tidak menentu. Apabila cuaca buruk, harga ikan akan menjadi sangat mahal, bahkan nelayan tak dapat melaut. Berdasarkan Indikator keluarga sejahtera Badan Pusat Statistik 2005 dalam Sugiharto (2007), pendapatan < Rp 5.000.000,- per bulan, merupakan pendapatan rendah. Menurut Sarempaa, dkk (2017), semakin banyak jumlah ikan, harga ikan turun, permintaan meningkat. Jika berkurang jumlah ikan, harga ikan naik dan permintaan berkurang. Menurut Tamarol \& Sarapil (2018), pendapatan nelayan juga bergantung pada jenis alat tangkap yang digunakan.

Menurut Hapsari (2013), pemasaran adalah kegiatan terpenting dalam usaha distribusi dan pemasaran ikan laut segar, dimana menjadi faktor penentu berjalannya usaha penjualan secara umum khususnya nelayan sebagai produsen. Pasar Manalu yang ada di Kecamatan Tabukan Selatan, merupakan salah satu pasar tradisional yang menjadi pusat transaksi jual beli bagi nelayan, pedagang pengumpul, pedagang pengecer, dan konsumen. Ada 3 jenis saluran pemasaran ikan demersal di
Pasar Manalu, seperti yang ditunjukkan pada Gambar 8.

Gambar 8. Saluran Pemasaran Ikan Demersal di Pasar Manalu.

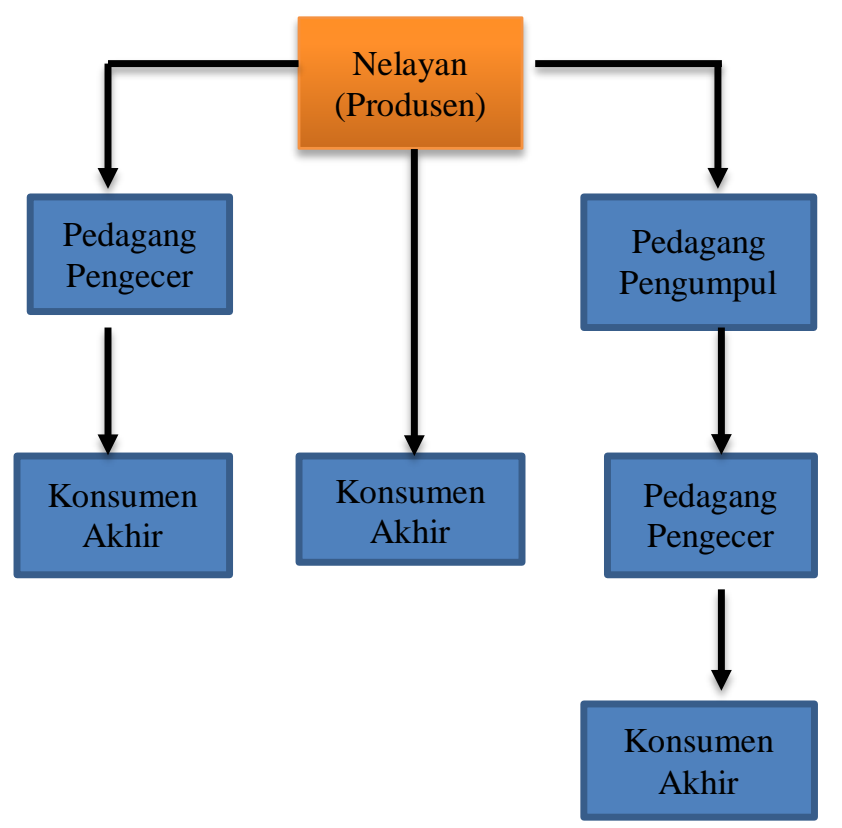

Ada 3 (tiga) alur pemasaran ikan demersal yang terjadi di pasar Manalu yaitu :

1. Nelayan menjual hasil tangkapan ikan ke konsumen akhir.

2. Nelayan menjual hasil tangkapan ke pedagang pengecer. Kemudian, Pedagang Pengecer menjual ke konsumen akhir.

3. Nelayan menjual hasil tangkapan ikan ke Pedagang pengumpul. Pedagang Pengumpul menjual ke Pedagang pengecer, Pedagang pengecer menjual ke konsumen akhir.

Margin pemasaran merupakan perbedaan harga yang dibayar antara penjual pertama dan pembeli terakhir (Huda, dkk, 2015). Margin pemasaran ikan demersal pada Saluran kedua, yaitu sebagai berikut.

$\mathrm{Pr}=$ Harga ditingkat konsumen (Pedagang pengecer $)=$ Rp. $35.000 / \mathrm{kg}$ $\mathrm{Pf}=$ Harga diterima produsen (Nelayan) $=$ Rp. $20.000 / \mathrm{kg}$

$\mathbf{M}=\mathbf{P r}-\mathbf{P f}$ 
$\mathrm{M}=\mathrm{Rp} 15.000,-$

$M_{p}=\left(\frac{P_{r}-P_{f}}{P_{r}}\right) \times 100 \%$

$M_{p}=43 \%$

Bagian-bagian yang diterima produsen adalah sebagai berikut.

$\mathrm{F}=\left(\mathbf{1}-\frac{\boldsymbol{M}}{\boldsymbol{P}_{r}}\right) \times 100 \%$

$\mathrm{F}=0,57 \times 100 \%=57 \%$

Nilai $\mathrm{F}>50 \%$, hal ini menunjukkan bahwa pemasaran ikan demersal yang ada Pasar Manalu. Sekalipun pemasaran sudah efesien, tetapi kesejahteraan nelayan tidak bertambah. Salah satu penyebabnya yaitu gaya hidup nelayan dimana mereka tidak dapat mengatur keuangan dengan baik, seperti boros dan suka minum minuman beralkohol. Menurut Sarapil \& Wuaten (2017), pola hidup nelayan cenderung konsumtif dan kurangnya kesadaran untuk menabung. Zebua, dkk (2017), menyebutkan bahwa rendahnya tingkat kesejahteraan nelayan diantaranya karena teknologi penangkapan yang terbatas dan kebiasaan yang buruk dalam pengelolaan keuangan.

\section{KESIMPULAN}

Umumnya, nelayan penangkap ikan demersal di Kampung Laotongan menggunakan alat tangkap hand line, dalam Bahasa lokal disebut Kakintu. Serta, perahu yang digunakan adalah perahu jenis pumpboat. Nelayan di Kampung Laotongan merupakan nelayan dengan pendapatan yang rendah, serta sebagian besar nelayan mempunyai pendidikan tingkat SD. Margin pemasaran ikan demersal sebesar Rp. 15.000., dan nilai efesiensi bagian yang diterima nelayan, $F=57 \%, F>50 \%$, dimana hasil penjualan ikan demersal sudah efisien. Namun, kesejahteraan nelayan tidak meningkat. Salah satu faktor yaitu gaya hidup nelayan yang boros. Pemerintah dapat lebih memperhatikan kesejahteraan nelayan.

\section{Ucapan Terima kasih}

Penulis menyampaikan terima kasih kepada Pemerintah kampung dan para nelayan di Pulau Tehang yang telah bersedia untuk diwawancarai. Serta, kepada para penjual yang ada di Pasar Manalu., Kecamatan Tabukan Selatan.

\section{DAFTAR PUSTAKA}

[1] Anonimous. 2015. Data Kampung Laotongan Kecamatan Tabukan Selatan. Pemerintah Kampung Laotongan Kecamatan Tabukan Selatan. Kabupaten Kepulauan Sangihe

[2] Firdaus, M. \& Witomo, C. M. 2014. Analisis Tingkat Kesejahteraan dan Ketimpangan Pendapatan Rumah Tangga Nelayan Pelagis Besar di Sendang Biru, Kabupaten Malang, Jawa Timur. Jurnal Sosial Ekonomi Kelautan \& Perikanan, 9(2): 155 168

[3] Hapsari, T. D. 2013. Distribusi dan Margin Pemasaran Hasil Tangkapan Ikan Tongkol (Euthynnus affinis) di TPI Ujungbatu Jepara. Jurnal Ilmu Perikanan dan Sumberdaya Perairan, 2(2): $131-138$

[4] Huda, M., Solihin, I., \& Lubis, E. 2015. Tingkat Efisien Pemasaran Ikan Laut Segar di Pelabuhan Perikanan Nusantara Brondong. Jurnal Teknologi Perikanan dan Kelautan, 6(1): 91 - 104

[5] Rosin. 2017. Analisis Tingkat Kesejahteraan Masyarakat Nelayan di Desa Dahari Selebar Kecamatan Talawi Kabupaten Batubara. Jurnal Geografi, 9(1): 53 - 66

[6] Sarapil, C. I. \& Lungari, F. F. 2017. Analisis Kesiapan Teknologi Komponen Humanware Kelompok Nelayan di Tidore dan Santiago Berdasarkan Jenis Alat Tangkap. Jurnal Ilmiah Tindalung, 3(2): 55 59 
[7] Sarapil, C. I., Tamarol, J., \& Kumaseh, E. I. 2019. Potret Masyarakat Nelayan Penangkap Ikan di Pulau Lipang Kecamatan Kendahe Kabupaten Kepulauan Sangihe Propinsi Sulawesi Utara. Jurnal Ilmiah Tindalung, 5(2): $61-70$

[8] Sarapil, C. I. \& Wuaten, J. F. 2017. Manajemen Rumah Tangga Nelayan Penangkap Ikan Tuna (Thunnus albacores) Studi Kasus di Pesisir Pantai Akembuala Kelurahan Santiago Kecamatan Tahuna Kabupaten Kepulauan Sangihe. Jurnal Ilmiah Tindalung, 3(1): 23 30

[9] Sarempaa, E. S., Mantjoro, E. \& Lumenta, V. 2017. Kondisi Perusahaan Perikanan di Kota Bitung Pasca Moratorium 2014. Akulturasi: Jurnal Ilmiah Agrobisnis Perikanan, 5(9): 677 - 686

[10] Subadi Tjipto, 2004. Penelitian Kualitatif. Cet 1, Surakarta; Penerbit Muhammadiyah University Press Universitas Muhammadiyah Surakarta. 124 hal

[11] Sugiharto, E. 2007. Tingkat Kesejahteraan Masyarakat Nelayan Desa Benua Baru Ilir Berdasarkan Indikator Badan Pusat Statistik.
Jurnal Ekonomi Pembangunan dan Perencanaan, 4(2): 32 - 36

[12] Tamarol, J., \& Sarapil, C. I. 2018. Kajian Sosial Ekonomi Rumah Tangga Nelayan Pancing Ulur (Hand line) Perorangan di Kecamatan Tabukan Utara Kabupaten Sangihe. Jurnal Ilmiah Tindalung, 4(2): 89 98

[13] Triyanti, R. \& Shafitri, N. 2012. Kajian Pemasaran Ikan Lele (Clarias Sp) Dalam Mendukung Industri Perikanan Budidaya (Studi Kasus di Kabupaten Boyolali, Jawa Tengah. Jurnal Sosial Ekonomi Kelautan \& Perikanan, 7(2): 177 - 191

[14] Yapanani, E., Solichin, A., \& Argo W., B. 2013. Kajian Hasil Tangkapan dan Tingkat Kesejahteraan Nelayan di Desa Aromarea Distrik Kosiwo, Kabupaten Sarui Kepulauan Yapen, Papua. Journal of Management of Aquatic Resources, 2(3): 197 - 202

[15] Zebua, Y., Wildani, P. K., Lasefa, A., \& Rahmad, R. 2017. Faktor Penyebab Rendahnya Tingkat Kesejahteraan Nelayan Pesisir Pantai Sri Mersing Desa Kuala Lama Kabupaten Serdang Bedagai Sumatera Utara. Jurnal Geografi, 9(1): 88 - 98 